\title{
Effect of Integrated Nutrient Management on Growth, Yield and Economics of Wheat (Triticum aestivum L.) in Inceptisol
}

\author{
K. Reddy Tummala ${ }^{1 *}$, R.B. Pawar ${ }^{2}$ and D.S. Patil ${ }^{2}$ \\ ${ }^{1}$ M.Sc agri Soil Science and Agril. Chemistry, Rajarshee Chhatrapati Shahu Maharaj College \\ of Agriculture, Kolhapur. \\ ${ }^{2}$ Division of Soil Science and Agril. Chemistry, Rajarshee Chhatrapati Shahu Maharaj \\ College of Agriculture, Kolhapur. \\ *Corresponding author
}

\section{Keywords}

INM, Wheat, FYM,

PMC,

Vermicompost

Article Info

Accepted:

15 September 2018

Available Online:

10 October 2018

\section{A B S T R A C T}

The present investigation was undertaken at Post Graduate Research Farm, College of Agriculture, Kolhapur during rabi 2016 with the objective to study the effect of integrated nutrient management on growth, yield and economics of wheat in Inceptisol. The experiment was laid out in a randomized block design with three replications and ten treatments. Studies revealed that the growth characters, yield attributes, grain and stover yields were influenced significantly due to conjunctive use of different organic manures with inorganic fertilizers. Amongst different treatments, the highest plant height (91.13 $\mathrm{cm})$, total number of tillers meter ${ }^{-1}(412)$, length of panicle $(8.40 \mathrm{~cm})$, number of grains panicle $^{-1}(36)$, thousand grain weight $(41.83 \mathrm{~g})$, grain weight panicle ${ }^{-1}(1.92 \mathrm{~g})$, grain $\left(43.43 \mathrm{q} \mathrm{ha}^{-1}\right)$ and stover $\left(62.33 \mathrm{q} \mathrm{ha}^{-1}\right)$ yields, gross monetary returns $(82.22$ thousand₹ . $\mathrm{ha}^{-1}$ ) and $\mathrm{B}$ : C ratio (2.98) were recorded in treatment $\mathrm{T}_{4}$ i.e. with application of $75 \%$ inorganic $\mathrm{RDN}+25 \% \mathrm{RDN}$ through $\mathrm{PMC}+\mathrm{RD}$ of $\mathrm{P}_{2} \mathrm{O}_{5}$ and $\mathrm{K}_{2} \mathrm{O}$, which was at par with treatment $\mathrm{T}_{2}$. The results of the present investigation indicate that it is possible to replace $25 \%$ inorganic nitrogen through organic manures viz: PMC, VC and FYM with maintaining yield and organic carbon status of soil.

\section{Introduction}

Wheat (Triticum aestivum L.) is the World's most important widely cultivated food crop. World production of wheat was estimated to be 734.1 million tonnes during 2015-16. Wheat is the staple food crop which occupies important place next to rice in India.

In India, during the past three decades, intensive agriculture involving exhaustive high-yielding varieties of wheat has led to heavy withdrawal of nutrients from the soil. Since then, there was a continuous increase in fertilizer consumption too. Furthermore, imbalanced use of chemical fertilizers by farmers has deteriorated soil health which ultimately laid path for declining productivity.

Integrated nutrient supply is the systematic approach to nutrient management as the combined application of organic and inorganic sources improves the soil fertility and crop productivity (Shree et al., 2014). Remarkable increase in nutrient uptake and yield by integrated nutrient supply has also been reported by Mohanty et al., (2013). In view of this, the present investigation was undertaken 
to study the effect of integrated nutrient management on growth, yield and economics of wheat in Inseptisol.

\section{Materials and Methods}

The field experiment was carried out during rabi, 2016 in the randomized block design with ten treatments replicated thrice. The sowing of seeds of wheat cv. PhuleSamadhan (NIAW-1994) was done by line sowing by hand at $2-3 \mathrm{~cm}$ depth of soil and with line to line spacing of $22.5 \mathrm{~cm}$ to maintain uniform plant population. Treatments superimposed were $\mathrm{T}_{1}$-Absolute control, $\mathrm{T}_{2}$-RDN $+\mathrm{RD}$ of $\mathrm{P}_{2} \mathrm{O}_{5}$ and $\mathrm{K}_{2} \mathrm{O}, \mathrm{T}_{3}-75 \%$ inorganic $\mathrm{RDN}+25 \%$ RDN through FYM +RD of $\mathrm{P}_{2} \mathrm{O}_{5}$ and $\mathrm{K}_{2} \mathrm{O}$, $\mathrm{T}_{4}-75 \%$ inorganic $\mathrm{RDN}+25 \% \mathrm{RDN}$ through $\mathrm{PMC}+\mathrm{RD}$ of $\mathrm{P}_{2} \mathrm{O}_{5}$ and $\mathrm{K}_{2} \mathrm{O}, \mathrm{T}_{5}-75 \%$ inorganic $\mathrm{RDN}+25 \% \mathrm{RDN}$ through Vermicompost + RD of $\mathrm{P}_{2} \mathrm{O}_{5}$ and $\mathrm{K}_{2} \mathrm{O}, \mathrm{T}_{6}-$ $50 \%$ inorganic $\mathrm{RDN}+50 \% \mathrm{RDN}$ through $\mathrm{FYM}+\mathrm{RD}$ of $\mathrm{P}_{2} \mathrm{O}_{5}$ and $\mathrm{K}_{2} \mathrm{O}, \mathrm{T}_{7}-50 \%$ inorganic RDN $+50 \%$ RDN through PMC + $\mathrm{RD}$ of $\mathrm{P}_{2} \mathrm{O}_{5}$ and $\mathrm{K}_{2} \mathrm{O}, \mathrm{T}_{8}-50 \%$ inorganic RDN $+50 \%$ RDN through Vermicompost + RD of $\mathrm{P}_{2} \mathrm{O}_{5}$ and $\mathrm{K}_{2} \mathrm{O}, \mathrm{T}_{9}-100 \%$ RDN through organics (33\% FYM + 33\% PMC + 33\% V.C) $+\mathrm{RD}$ of $\mathrm{P}_{2} \mathrm{O}_{5}$ and $\mathrm{K}_{2} \mathrm{O}, \mathrm{T}_{10}$-Green manuringin situ of sunnhemp $(2: 1$; wheat: sunnhemp) + $\mathrm{RD}$ of $\mathrm{P}_{2} \mathrm{O}_{5}$ and $\mathrm{K}_{2} \mathrm{O}$. FYM, PMC, Vermicompost were applied as per the treatments 15 days before sowing. Out of total recommended dose of fertilizer (120: 60: 40; $\mathrm{N}: \mathrm{P}_{2} \mathrm{O}_{5}: \mathrm{K}_{2} \mathrm{O} \mathrm{kg} \mathrm{ha}{ }^{-1}$ ) a basal dose of 60: 60: 40; $\mathrm{N}: \mathrm{P}_{2} \mathrm{O}_{5}: \mathrm{K}_{2} \mathrm{O} \mathrm{kg} \mathrm{ha}^{-1}$ was applied through urea, single super phosphate and muriate of potash and different organic manures as per the treatment details, except absolute control. The remaining half dose of nitrogen i.e., $60 \mathrm{~kg}$ $\mathrm{ha}^{-1}$ was applied at 25 days after sowing through urea except absolute control. At maturity, the observations on ancillary characters were recorded on randomly selected plants in each plot. The wheat crop was harvested when grains were fully matured and straw turned yellow. The total grain and straw yield were recorded. The plant and soil samples collected at harvest were analysed for different parameters by adopting standard procedures.

\section{Results and Discussion}

\section{Effect of integrated nutrient management on growth and yield attributes}

Data illustrated in Table 1 and graphically depicted in Figure 1, 2 and 3 reveal that the growth and yield of wheat were increased significantly with conjunctive use of different organic manures with inorganic fertilizers over control. The significantly highest number of tillers meter ${ }^{-1}$ (412) was recorded with the treatment $\mathrm{T}_{4}$ however it was at par with $\mathrm{T}_{5}$ (407).

The significantly highest number of grains panicle $^{-1}$ was recorded with treatment $\mathrm{T}_{4}(36)$, however it was at par with $\mathrm{T}_{5}$ (34). The treatment $\mathrm{T}_{4}$ recorded significantly more plant height $(91.13 \mathrm{~cm})$, however it was at par with $\mathrm{T}_{5}$ (89.93), $\mathrm{T}_{3}$ (88.40), $\mathrm{T}_{2}(87.73)$ and $\mathrm{T}_{7}$ (84.06). The treatment $\mathrm{T}_{4}$ recorded significantly highest panicle length $(8.40 \mathrm{~cm})$, however it was at par with $\mathrm{T}_{5}(8.20 \mathrm{~cm}), \mathrm{T}_{3}$ $(8.06 \mathrm{~cm}), \mathrm{T}_{2}(8 \mathrm{~cm}), \mathrm{T}_{7}(7.40 \mathrm{~cm}), \mathrm{T}_{8}(7.20$ $\mathrm{cm})$ and $\mathrm{T}_{6}(7 \mathrm{~cm})$. These results are in confirmative with those reported by Nehra et al., (2001), Bahadur et al., (2013) and Singh et al., (2018).

The significantly highest thousand grain weight was recorded with treatment $\mathrm{T}_{4}(41.83$ $\mathrm{g})$, however it was at par with $\mathrm{T}_{5}(41.40 \mathrm{~g}), \mathrm{T}_{3}$ $(40.76 \mathrm{~g}), \mathrm{T}_{2}(40.30 \mathrm{~g}), \mathrm{T}_{7}(39.70 \mathrm{~g})$ and $\mathrm{T}_{8}$ $(39.13 \mathrm{~g})$. The significantly highest grain weight panicle ${ }^{-1}$ was recorded with treatment $\mathrm{T}_{4}(1.92 \mathrm{~g})$, however it was at par with $\mathrm{T}_{5}$ $(1.85 \mathrm{~g}), \mathrm{T}_{3}(1.79 \mathrm{~g})$ and $\mathrm{T}_{2}(1.70 \mathrm{~g})$. These results are confirmative with those reported by Bahadur et al., (2013) and Singh et al., (2018). 


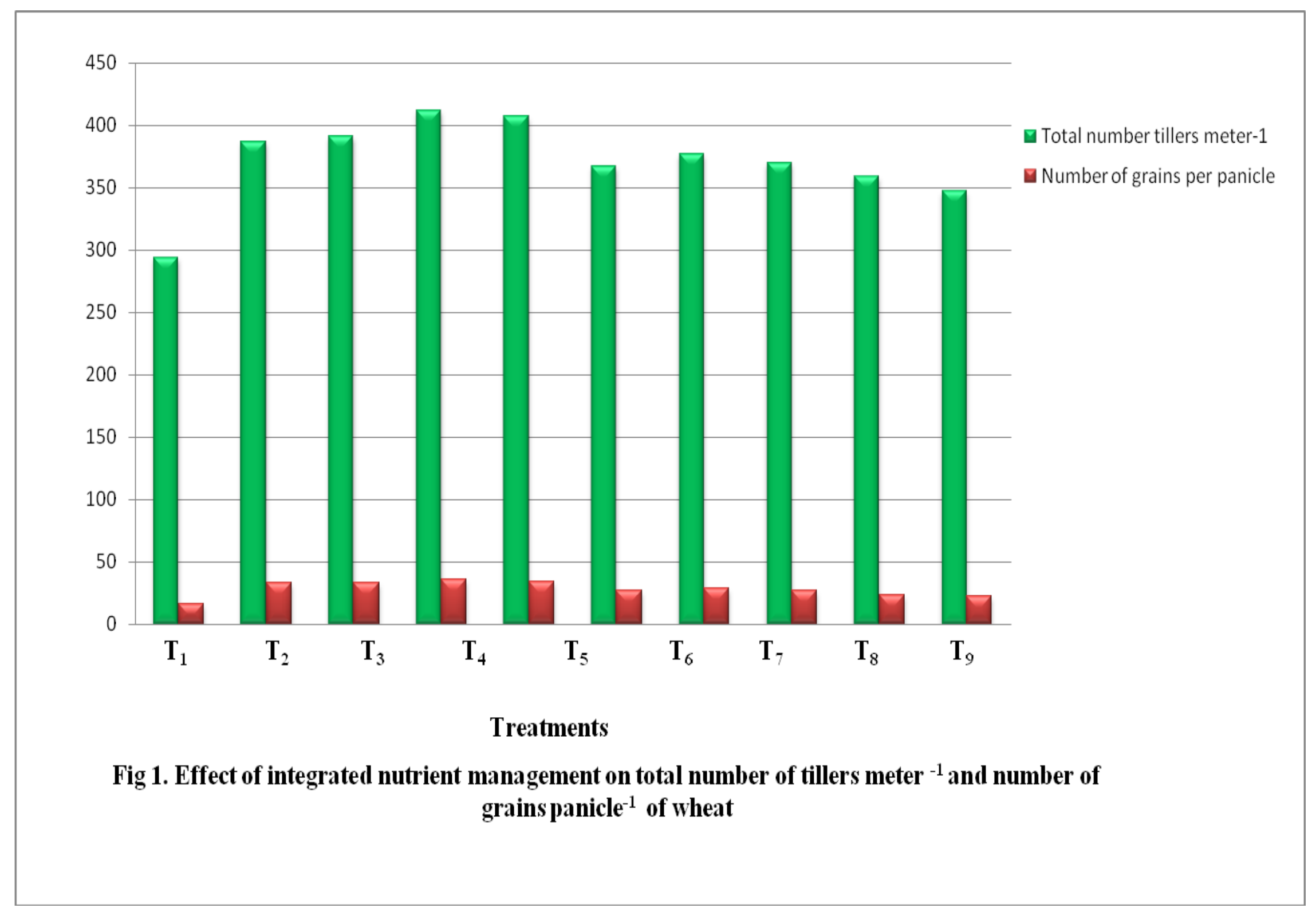


Int.J.Curr.Microbiol.App.Sci (2018) 7(10): 1892-1902

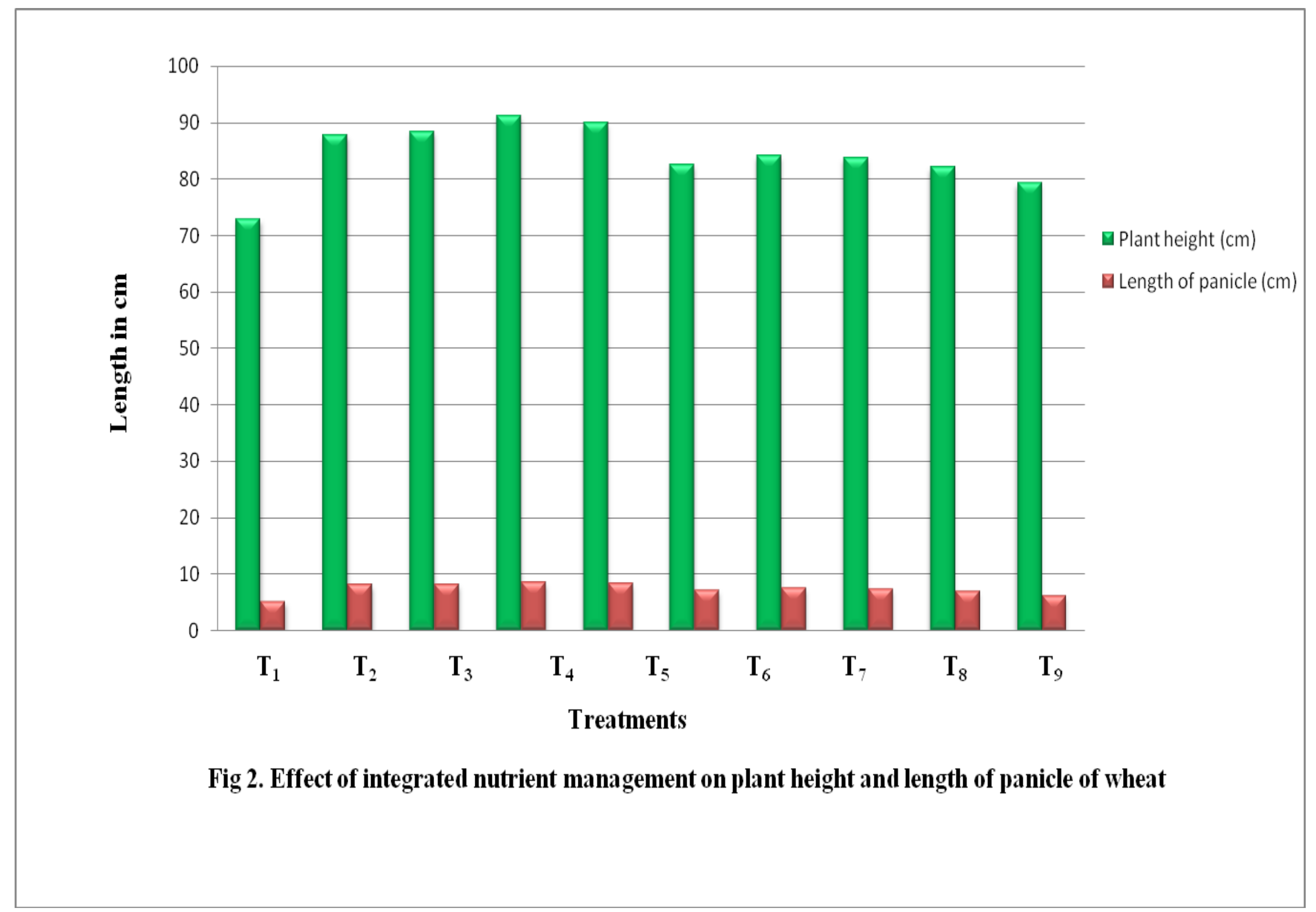


Int.J.Curr.Microbiol.App.Sci (2018) 7(10): 1892-1902

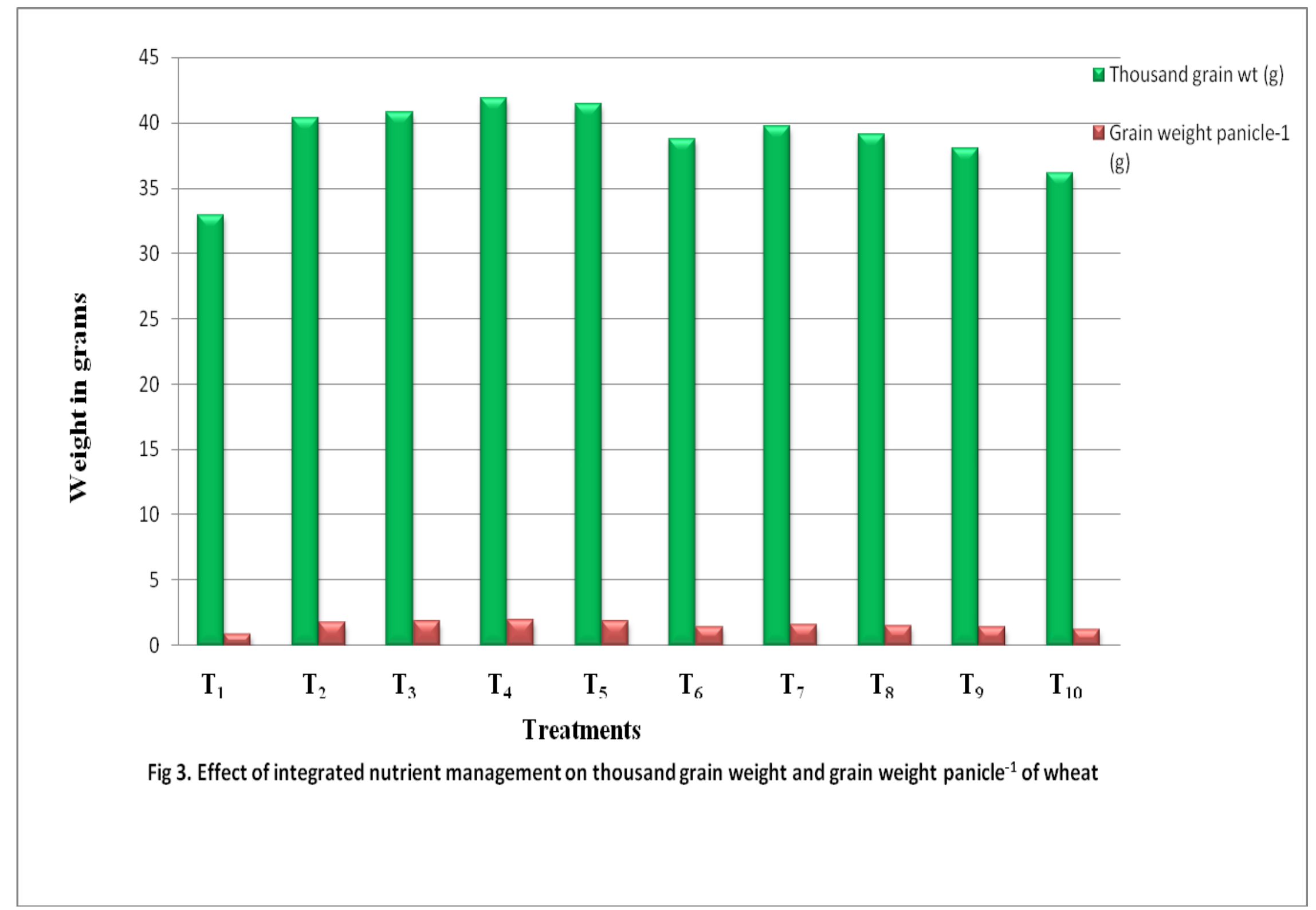


Int.J.Curr.Microbiol.App.Sci (2018) 7(10): 1892-1902

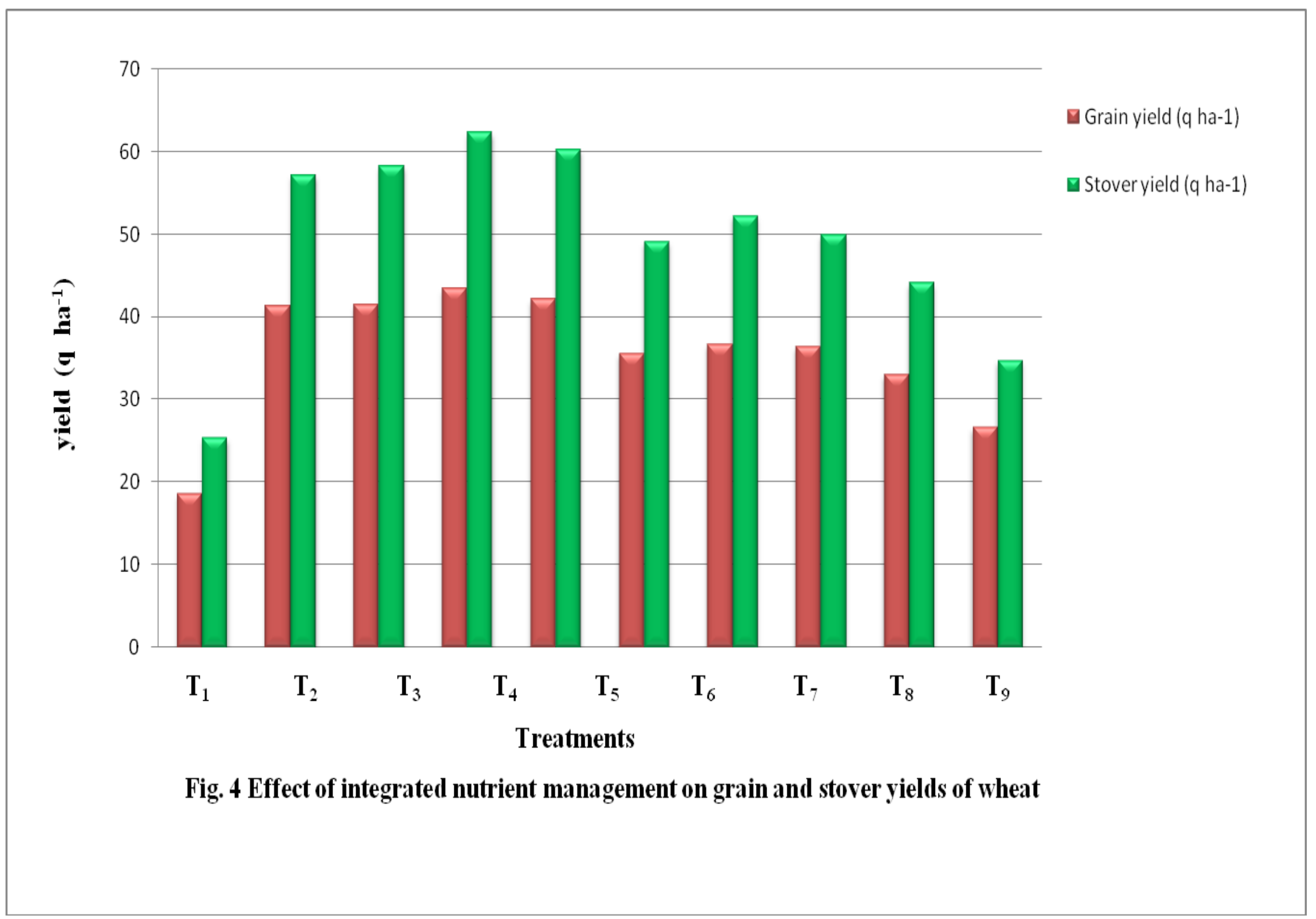


Int.J.Curr.Microbiol.App.Sci (2018) 7(10): 1892-1902

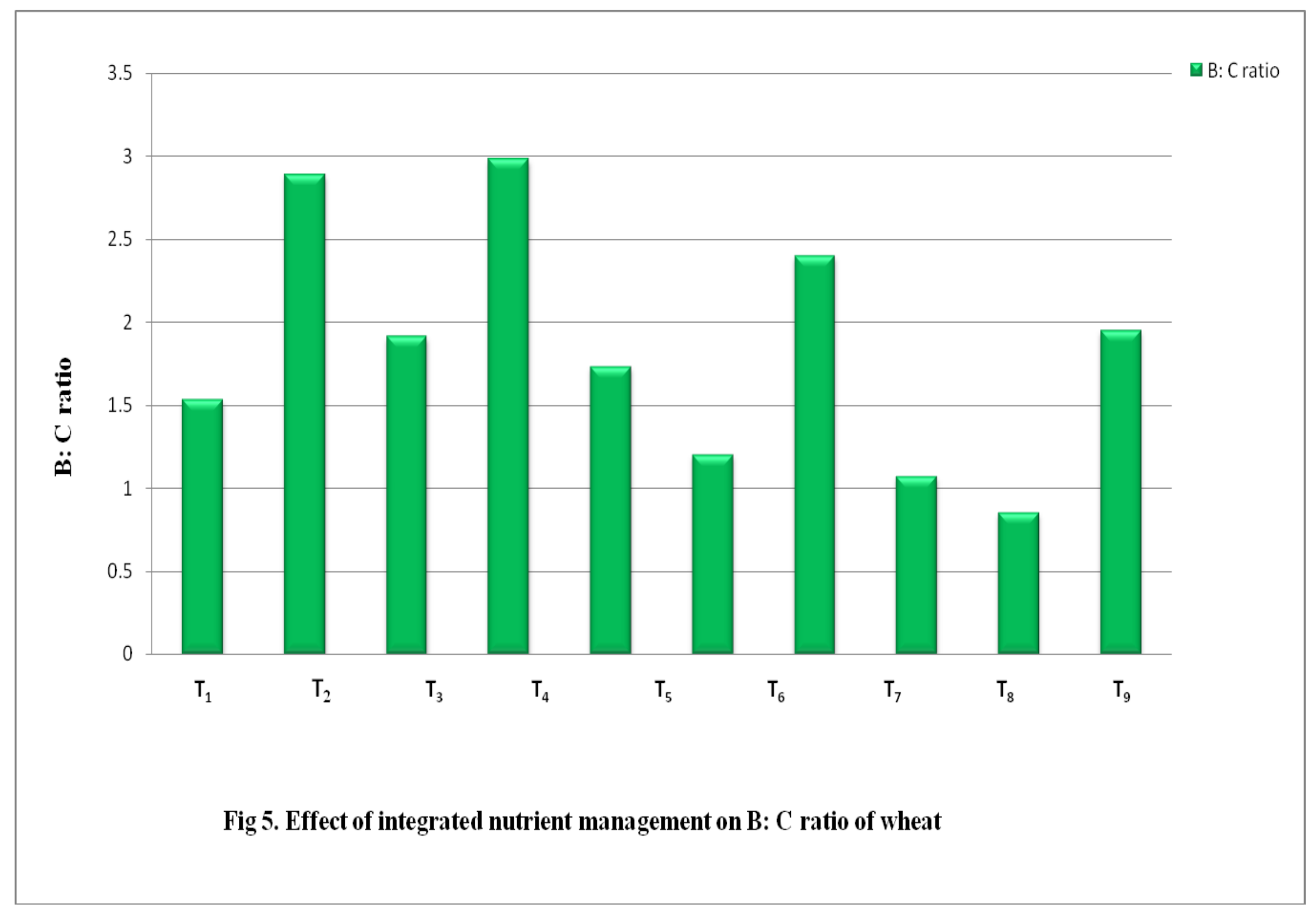




\section{Int.J.Curr.Microbiol.App.Sci (2018) 7(10): 1892-1902}

Table.1 Growth and yield attributing characters and yield of wheat as influenced by integrated nutrient management (INM)

\begin{tabular}{|c|c|c|c|c|c|c|c|c|}
\hline Treatment & $\begin{array}{l}\text { Total number } \\
\text { of tillers meter }\end{array}$ & $\begin{array}{c}\text { Number of } \\
\text { grains } \\
\text { panicle }^{-1}\end{array}$ & $\begin{array}{l}\text { Plant } \\
\text { height } \\
\text { (cm) }\end{array}$ & $\begin{array}{l}\text { Length } \\
\text { of } \\
\text { panicle } \\
\text { (cm) }\end{array}$ & $\begin{array}{l}\text { Thousand } \\
\text { grain wt } \\
\text { (g) }\end{array}$ & $\begin{array}{c}\text { Grain } \\
\text { weight } \\
\text { panicle }^{-1} \\
\text { (g) }\end{array}$ & $\left.\begin{array}{l}\text { Grain } \\
\text { yield } \\
\left(\mathbf{q} \text { ha }^{-}\right. \\
1\end{array}\right)$ & $\begin{array}{l}\text { Stover } \\
\text { yield } \\
\left(\mathbf{q} \mathbf{h a}^{-}\right. \\
1)\end{array}$ \\
\hline $\mathrm{T}_{1}$ (Absolute Control) & 294 & 16 & 72.80 & 5.06 & 32.93 & 0.86 & 18.56 & 25.32 \\
\hline $\mathrm{T}_{2} \mathrm{RDN}+\mathrm{RD}$ of $\mathrm{P}_{2} \mathrm{O}_{5} \& \mathrm{~K}_{2} \mathrm{O}$ & 387 & 33 & 87.73 & 8.00 & 40.30 & 1.70 & 41.27 & 57.18 \\
\hline $\begin{array}{l}\mathrm{T}_{3} 75 \% \mathrm{RDN}+25 \% \mathrm{RDN} \text { through FYM }+ \\
\mathrm{RD} \text { of } \mathrm{P}_{2} \mathrm{O}_{5} \& \mathrm{~K}_{2} \mathrm{O}\end{array}$ & 391 & 33 & 88.40 & 8.06 & 40.76 & 1.79 & 41.53 & 58.32 \\
\hline $\begin{array}{l}\mathrm{T}_{4} 75 \% \mathrm{RDN}+25 \% \mathrm{RDN} \text { through PMC + } \\
\mathrm{RD} \text { of } \mathrm{P}_{2} \mathrm{O}_{5} \& \mathrm{~K}_{2} \mathrm{O}\end{array}$ & 412 & 36 & 91.13 & 8.40 & 41.83 & 1.92 & 43.43 & 62.33 \\
\hline $\begin{array}{l}\mathrm{T}_{5} 75 \% \mathrm{RDN}+25 \% \mathrm{RDN} \text { through } \mathrm{VC}+ \\
\mathrm{RD} \text { of } \mathrm{P}_{2} \mathrm{O}_{5} \& \mathrm{~K}_{2} \mathrm{O}\end{array}$ & 407 & 34 & 89.93 & 8.20 & 41.40 & 1.85 & 42.15 & 60.29 \\
\hline $\begin{array}{l}\mathrm{T}_{6} 50 \% \mathrm{RDN}+50 \% \mathrm{RDN} \text { through FYM + } \\
\mathrm{RD} \text { of } \mathrm{P}_{2} \mathrm{O}_{5} \& \mathrm{~K}_{2} \mathrm{O}\end{array}$ & 367 & 27 & 82.53 & 7.00 & 38.76 & 1.42 & 35.57 & 49.16 \\
\hline $\begin{array}{l}\mathrm{T}_{7} 50 \% \mathrm{RDN}+50 \% \mathrm{RDN} \text { through PMC }+ \\
\mathrm{RD} \text { of } \mathrm{P}_{2} \mathrm{O}_{5} \& \mathrm{~K}_{2} \mathrm{O}\end{array}$ & 377 & 29 & 84.06 & 7.40 & 39.70 & 1.55 & 36.71 & 52.28 \\
\hline $\begin{array}{l}\mathrm{T}_{8} 50 \% \mathrm{RDN}+50 \% \mathrm{RDN} \text { through } \mathrm{VC}+ \\
\mathrm{RD} \text { of } \mathrm{P}_{2} \mathrm{O}_{5} \& \mathrm{~K}_{2} \mathrm{O}\end{array}$ & 370 & 27 & 83.73 & 7.20 & 39.13 & 1.49 & 36.46 & 49.96 \\
\hline $\begin{array}{l}\mathrm{T}_{9} 100 \% \text { RDN through }(33 \% \mathrm{FYM}+33 \% \\
\mathrm{PMC}+33 \% \text { VC) }+\mathrm{RD} \text { of } \mathrm{P}_{2} \mathrm{O}_{5} \& \mathrm{~K}_{2} \mathrm{O}\end{array}$ & 359 & 23 & 82.00 & 6.86 & 37.97 & 1.34 & 33.00 & 44.10 \\
\hline $\begin{array}{l}\mathrm{T}_{10} \text { Green manuring in situ } \\
\left(2: 1 ; \text { wheat:sunnhemp) } \mathrm{RD} \text { of } \mathrm{P}_{2} \mathrm{O}_{5} \& \mathrm{~K}_{2} \mathrm{O}\right.\end{array}$ & 347 & 22 & 79.26 & 6.00 & 36.09 & 1.21 & 26.62 & 34.77 \\
\hline S.E \pm & 4.51 & 0.94 & 2.39 & 0.49 & 0.96 & 0.09 & 1.51 & 1.95 \\
\hline C.D. $(P=0.05)$ & 13.40 & 2.80 & 7.12 & 1.46 & 2.86 & 0.27 & 4.48 & 5.80 \\
\hline
\end{tabular}


Table. 2 Gross monetary returns, cost of cultivation, net monetary returns and B: C ratio of wheat crop as influenced by integrated nutrient management (INM)

\begin{tabular}{|c|c|c|c|c|c|c|}
\hline Treatment & $\begin{array}{l}\text { Grain } \\
\text { yield } \\
\left(\mathbf{q} \mathbf{h a}^{-1}\right)\end{array}$ & $\begin{array}{l}\text { Stover } \\
\text { yield } \\
\left(\mathbf{q} \mathbf{h a}^{-1}\right)\end{array}$ & $\begin{array}{l}\text { Gross } \\
\text { monetary } \\
\text { returns } \\
(\text { thousand } \\
\text { ₹. ha' } \\
\text {.1 })\end{array}$ & $\begin{array}{l}\text { Cost of } \\
\text { cultivation } \\
\text { (thousand } \\
\left.₹ \cdot h^{-1}\right)\end{array}$ & $\begin{array}{c}\text { Net } \\
\text { monetary } \\
\text { returns } \\
(\text { thousand } \\
\text { ₹.ha'-1) }\end{array}$ & $\begin{array}{l}\text { B:C } \\
\text { ratio }\end{array}$ \\
\hline $\mathrm{T}_{1}$ (Absolute Control) & 18.56 & 25.32 & 35.02 & 22.83 & 34.15 & 1.53 \\
\hline $\mathrm{T}_{2} \mathrm{RDN}+\mathrm{RD}$ of $\mathrm{P}_{2} \mathrm{O}_{5} \& \mathrm{~K}_{2} \mathrm{O}$ & 41.27 & 57.18 & 75.94 & 26.21 & 49.73 & 2.89 \\
\hline $\begin{array}{l}\mathrm{T}_{3} 75 \% \mathrm{RDN}+25 \% \mathrm{RDN} \text { through } \\
\text { FYM + RD of } \mathrm{P}_{2} \mathrm{O}_{5} \& \mathrm{~K}_{2} \mathrm{O}\end{array}$ & 41.53 & 58.32 & 78.33 & 40.84 & 37.48 & 1.91 \\
\hline $\begin{array}{l}\mathrm{T}_{4} 75 \% \mathrm{RDN}+25 \% \mathrm{RDN} \text { through } \\
\mathrm{PMC}+\mathrm{RD} \text { of } \mathrm{P}_{2} \mathrm{O}_{5} \& \mathrm{~K}_{2} \mathrm{O}\end{array}$ & 43.43 & 62.33 & 82.22 & 27.51 & 54.71 & 2.98 \\
\hline $\begin{array}{l}\mathrm{T}_{5} 75 \% \mathrm{RDN}+25 \% \mathrm{RDN} \text { through } \\
\mathrm{VC}+\mathrm{RD} \text { of } \mathrm{P}_{2} \mathrm{O}_{5} \& \mathrm{~K}_{2} \mathrm{O}\end{array}$ & 42.15 & 60.29 & 79.79 & 44.90 & 34.88 & 1.77 \\
\hline $\begin{array}{l}\mathrm{T}_{6} 50 \% \mathrm{RDN}+50 \% \mathrm{RDN} \text { through } \\
\text { FYM + RD of } \mathrm{P}_{2} \mathrm{O}_{5} \& \mathrm{~K}_{2} \mathrm{O}\end{array}$ & 35.57 & 49.16 & 67.17 & 55.48 & 11.69 & 1.20 \\
\hline $\begin{array}{l}\mathrm{T}_{7} 50 \% \mathrm{RDN}+50 \% \mathrm{RDN} \text { through } \\
\mathrm{PMC}+\mathrm{RD} \text { of } \mathrm{P}_{2} \mathrm{O}_{5} \& \mathrm{~K}_{2} \mathrm{O}\end{array}$ & 36.71 & 52.28 & 69.48 & 28.81 & 40.65 & 2.40 \\
\hline $\begin{array}{l}\mathrm{T}_{8} 50 \% \mathrm{RDN}+50 \% \mathrm{RDN} \text { through } \\
\mathrm{VC}+\mathrm{RD} \text { of } \mathrm{P}_{2} \mathrm{O}_{5} \& \mathrm{~K}_{2} \mathrm{O}\end{array}$ & 36.46 & 49.96 & 68.80 & 63.57 & 05.23 & 1.07 \\
\hline $\begin{array}{l}\mathrm{T}_{9} 100 \% \mathrm{RDN} \text { through (33\% FYM } \\
+33 \% \mathrm{PMC}+33 \% \mathrm{VC})+\mathrm{RD} \text { of } \\
\mathrm{P}_{2} \mathrm{O}_{5} \& \mathrm{~K}_{2} \mathrm{O}\end{array}$ & 33.00 & 44.10 & 62.15 & 72.35 & 0.21 & 0.85 \\
\hline $\begin{array}{l}\mathrm{T}_{10} \text { Green manuring in situ } \\
(2: 1 \text {; wheat:sunnhemp) } \mathrm{RD} \text { of } \\
\mathrm{P}_{2} \mathrm{O}_{5} \& \mathrm{~K}_{2} \mathrm{O}\end{array}$ & 26.62 & 34.77 & 50.07 & 25.59 & 21.81 & 1.95 \\
\hline S.E \pm & 1.51 & 1.95 & 2.74 & - & 6.67 & 0.08 \\
\hline C.D. $(P=0.05)$ & 4.48 & 5.80 & 8.16 & - & 19.84 & 0.26 \\
\hline
\end{tabular}

Effect of integrated nutrient management on grain and stover yield

The significantly highest grain (43.43 q ha $\left.{ }^{-1}\right)$ and Stover $\left(62.33 \mathrm{q} \mathrm{ha}^{-1}\right)$ yields of wheat were recorded in treatment $\mathrm{T}_{4}$ and it was at par with $\mathrm{T}_{5}, \mathrm{~T}_{3}$ and $\mathrm{T}_{2}$ as shown in Table 1 and graphically depicted in Figure 4. The results are confirmative with Bahadur et al., (2012).

The significantly highest grain and stover yields of wheat were recorded in the treatments receiving $25 \%$ GRDN through organic manures viz., FYM, PMC and VC which might be due to proper supply of $\mathrm{N}$ at different growth stages of wheat and other beneficial and favourable effect of organic manures on soil properties. Further substituting $50 \%$ inorganic $\mathrm{N}$ with organic $\mathrm{N}$ through different organic manures significantly reduced the grain and stover yield of wheat however, the yields were significantly higher than $100 \%$ RDN through organic manures $\left(\mathrm{T}_{9}\right)$ and green manuring of sunnhemp in situ $\left(\mathrm{T}_{10}\right)$.

The green manuring of sunnhemp in wheat increased the grain and stover yield of wheat 
significantly over absolute control $\left(\mathrm{T}_{1}\right)$ indicating the favourable effect of green manuring on soil and crop. These results are confirmative with those reported by Singh et al., (2018), Prasad et al., (2010) and Sharma et al., (2016), who also reported increase in grain and stover yields of wheat with integrated use of inorganic fertilizers and organic manures.

Gross monetary returns, net monetary returns and $B$ : $C$ ratio as influenced by integrated nutrient management

Gross monetary, cost of cultivation, net monetary returns and $\mathrm{B}$ : $\mathrm{C}$ ratio as influenced by different treatments are presented in Table 2 and graphically depicted in Figure 5.

The significantly highest gross monetary returns were obtained in treatment $\mathrm{T}_{4}(82.22$ thousand $₹$. ha ${ }^{-1}$ ) but it was at par with $\mathrm{T}_{5}, \mathrm{~T}_{3}$ and $\mathrm{T}_{2}$. The cost of wheat cultivation was significantly highest in treatment $\mathrm{T}_{9}(72.35$ thousand ₹. $\mathrm{ha}^{-1}$ ). The highest cost of cultivation in $\mathrm{T}_{9}$ treatment was due to application of $100 \%$ RD of nitrogen was supplied through organic manures where the cost of vermicompost and Farm Yard Manures were very high $₹ .8000 \mathrm{t}^{-1}$ and ₹.2500 $\mathrm{t}^{-1}$, respectively. The significantly highest B: C ratio (2.98) was recorded in $\mathrm{T}_{4}$ $(75 \% \mathrm{RDN}+25 \% \mathrm{RD}$ of nitrogen through $\mathrm{PMC}+\mathrm{RD}$ of $\mathrm{P}_{2} \mathrm{O}_{5}$ and $\mathrm{K}_{2} \mathrm{O}$ ). These results are confirmative with Ram et al., (2014) and Singh et al., (2016).

There was significant increase in plant height, number of tillers meter ${ }^{-1}$, length of panicle, thousand grains weight, grain weight panicle ${ }^{1}$, number of grains panicle ${ }^{-1}$, grain and stover yield over the control due to integrated application of organic manures with inorganic fertilizers. The highest $\mathrm{B}$ : $\mathrm{C}$ ratio was recorded with treatment $\mathrm{T}_{4}(75 \% \mathrm{RDN}+25 \%$ $\mathrm{RD}$ of nitrogen through $\mathrm{PMC}+\mathrm{RD}$ of $\mathrm{P}_{2} \mathrm{O}_{5}$ and $\mathrm{K}_{2} \mathrm{O}$ ) however it was at par with treatment $\mathrm{T}_{2}\left(\mathrm{RDN}+\mathrm{RD}\right.$ of $\mathrm{P}_{2} \mathrm{O}_{5}$ and $\left.\mathrm{K}_{2} \mathrm{O}\right)$. The substitution of $25 \%$ RDN through press mud cake significantly increased all the growth parameters, grain and stover yield of wheat. The results of the present investigation indicate that it is possible to replace $25 \%$ inorganic nitrogen through organic manures viz., PMC, VC and FYM with maintaining yield and organic carbon status of soil.

\section{References}

Bahadur, L., Tiwari, D.D., Mishra, J. and Gupta, B.R. (2012) Effect of integrated nutrient management on yield, microbial population and changes in soil properties under rice-wheat cropping system in sodic soil. Journal of the Indian Society of Soil Science60, 326-329.

Bahadur, L., Tiwari, D.D., Mishra, J. and Gupta, B.R. (2013) Evaluation of integrated nutrient management options in rice (Oryza sativa)-wheat (Triticum aestivum) cropping system in reclaimed sodic land. Indian Journal of Agronomy 58, 137-145.

Mohanty, M., Nanda, S.S. and Barik, A.K. (2013) Effect of integrated nutrient management on growth, yield, nutrient uptake and economics of wet season rice (Oryza sativa) in Odisha. Indian Journal of Agricultural Science 83, 599604.

Nehra, A.S., Hooda, I.S. and Singh, K.P. (2001) Effect of integrated nutrient management on growth and yield of wheat (Triticum aestivum L.). Indian Journal of Agronomy 46, 112-117.

Prasad, J., Karmakar, S., Kumar, R. and Mishra, B. (2010) Influence of integrated nutrient management on yield and soil properties in maize-wheat cropping system in an Alfisol of 
Jharkhand. Journal of the Indian Society of Soil Science 58, 200-204.

Ram, M., Davari, M.R. and Sharma, S.N. (2014) Direct, residual and cumulative effects of organic manures and biofertilizers on yields, NPK uptake, grain quality and economics of wheat (Triticum aestivum L.) under organic farming of rice-wheat cropping system. Journal of Organic Systems 9, 16-29.

Sharma, S.A., Kumar, R., Rana, S.S., Guleria, G. and Negi, S.C. (2016) Effect of longterm integrated plant nutrition system (IPNS) in rice-wheat sequence on soil biological health. International Journal of Advances in Agricultural Sciences and Technology 3, 21-34.
Shree, S., Singh, V.K. and Kumar, R. (2014) Effect of integrated nutrient management on yield and quality of cauliflower. (Brassica Oleracea. Var. Botrytis L.). The Bioscan 9, 1053-1058. Singh, B. J., Trivedi, S.K., Verma, S.K., Prajapati, B.L., Singh, A. and Khan, S. (2016) Effect of integrated nutrient management on yield and nutrient uptake by wheat in alluvial soils of Madhya Pradesh. International Journal of Agriculture Sciences 8, 2206-2209.

Singh, G., Kumar, S., Sindhu, G.S., and Kaur, R. (2018) Effect of nutrient management on yield of wheat (Triticum aestivum L.) under irrigated conditions. International Journal of Chemical Studies 6, 904-907.

\section{How to cite this article:}

Reddy Tummala, K., R.B. Pawar and Patil, D.S. 2018. Effect of Integrated Nutrient Management on Growth, Yield and Economics of Wheat (Triticum aestivum L.) in Inceptisol. Int.J.Curr.Microbiol.App.Sci. 7(10): 1892-1902. doi: https://doi.org/10.20546/ijcmas.2018.710.218 